\title{
Renewable Energy Sources in Iran: Policy and Regulation
}

\author{
Mohsen Safari ${ }^{1} \&$ Fariborz Safari ${ }^{2}$ \\ ${ }^{1}$ Associated Professor in Energy/Civil Law, Tehran University, B.A., L.L.M, and PhD (Tehran University) \\ ${ }^{2}$ Assistant Professor in Energy/Trade Law, H. Masumeh, S. University, M.S.c. (Belgium); Ph.D. and \\ Post-doctorate in Law (Ireland) \\ Correspondence: Mohsen Safari, Associated Professor in Energy/Civil Law, Tehran University, B.A., L.L.M, and \\ PhD (Tehran University). E-mail: safarimohsen@ut.ac.ir
}

Received: June 19, 2017

doi:10.5539/jpl.v10n4p245
Accepted: July 19, $2017 \quad$ Online Published: August 30, 2017

URL: https://doi.org/10.5539/jpl.v10n4p245

\begin{abstract}
According to the Fifth Five Year Development Plan, in Iran, renewable resources, under the green horizon scenarios, must provide 5,000 MW of electricity. Among different types of renewable source of energy, there is no shortage of information in Iran, which is located near to zero line (earth's equator), with about 300 clear sunny days in a year, about setting policies promoting solar energy. Taking into account the availability and benefits of solar energy for Iran, this paper has focused on solar energy.

Recent statistics show that, if the current development plans proceed, the capacity of the installed renewable energy systems would reach $2.8 \mathrm{GW}$ by 2030 . This requires more than 2800 million US dollar investment in 20 years, i.e., 2010 to 2030. Despite the advantages of using solar energy, such as reducing greenhouse gases, it is important to note that solar power is 2.5 to 5 times as expensive as electricity from existing conventional power sources, such as coal and other sources. In order to encourage people to use solar power, there is a need to change our laws and establish an integrated energy regulation, involving tax policy mechanisms to support the deployment of solar energy in Iran. As Iran is dependent upon its fossil fuels, the transition from fossil fuels to renewable, which is a worldwide goal to reduce GHG or $\mathrm{CO} 2$ emissions, requires the adoption of a comprehensive policy and integrated regulation nationwide, taking a multidisciplinary approach. This paper exemplifies and considers the 2005 Energy Policy Act and Investment Tax Credit (ICT) for residential energy property, illustrating how solar-energy-regulation could contribute to the sustained development of solar energy. The main purpose is to help the development of sustainable solar energy regulation in Iran.
\end{abstract}

Keywords: Iran, renewable energy, solar energy, policy, regulation, tax law

\section{Introduction}

Under the Fifth Five Year Development Plan (The Fifth Five Year Economic, 2011), renewable resources in Iran are supposed to provide 5,000 MW of electricity. Najafi and et al, predict that the capacity of the installed renewable energy systems would reach $2.8 \mathrm{GW}$ by 2030 , which requires more than 2800 million US dollar investment in 2010-2030 (Najafi et al., 2015). In this respect, Alamdari and et al conducted feasibility studies across Iran on using solar energy, gathering data from 63 stations. The studies show that Iran's central and southern regions, except for the southern coastal areas, and Southern Khorasan and Khuzestan provinces, seem to be more reliable and beneficial to establish sites in those places, in terms of receiving high amounts of horizontal radiations (Alamdari et al., 2013). Another study has focused on three free economic and industrial zones of Iran, called Chabahar, Kish and Salafchegan. It also demonstrates a tremendous result, showing that all three regions have great potential solar and wind energy throughout the year suitable for utilizing different types of solar energy systems (Mohammadi et al., 2014). Some researchers have focused on special cities. For example, Khorasanizadeh, et al, evaluated 6 models to measure daily solar radiation data in four cities: Bandarabass, Isfahan, Kerman and Tabass (Khorasanizadeh \& Mohammadi, 2013). Such studies suggest that, practically, one of the major challenges for the establishment and development of every site is financing. Another challenge is the lack of necessary supportive regulations, which must be solved nationwide. All necessary legislative and administrative measures must be taken by the Government, on the one hand, and, the legislative bodies, on the other hand, to establish sustainable solar energy development. To encourage Iranian people we need to give the answer to one of the main questions as to what sustainable solar energy development is. 
Basically, energy from the sun that is converted into thermal or electrical energy is possibly the cleanest sources of energy we can get. As opposed to non-renewable (e.g. fossil fuels) energy sources, solar energy is a renewable energy source. Solar power reduces our use of fossil fuels and does not pollute. Usually harnessing solar energy does not cause pollution. Everyone has a responsibility to reduce his or her individual carbon footprint, which can be realized by means of using solar power. Indeed, using this kind of renewable energy can help reduce our individual carbon footprint, that is, the total amount of greenhouse gases (GHGs) produced, directly or indirectly, from human activities. ${ }^{1}$

Whether in the field of hydrocarbons or of renewable energy, the questions about the environment and pricing are, and will be, the most important questions for energy development now, and in the future.

The supply/demand imbalance price of oil, the deteriorating impacts of hydrocarbons on the environment, especially coastal areas, the social consequences of energy projects on society, as well as the fact that the vast majority of proven and probable reserves are in the hands of States or companies operating under the jurisdiction and control of a State, mean that solar renewable energy developments that would previously have been regarded as economically or technologically marginal are now high on the agenda. The pressure on hydrocarbons, together with binding targets to reduce $\mathrm{CO} 2$ emissions, within the context of climate change policy and law, means that potentially huge renewable energy projects are planned and implemented under the policy of sustainable energy development, nationwide and worldwide. However, at present there is no a multidisciplinary-integrated - especially regulatory - framework for solar renewable energy.

The focus of this paper is on the failure of the State to adopt a sustained regulation on solar renewable energy in Iran, as one of the main present legal and policy challenges to develop solar energy in Iran. As we discuss in this paper, there is a need to develop an integrated, holistic regulatory framework for solar energy which is considered as one of the forms of renewable energy, and as a serious contender in the energy market. Furthermore, this paper outlines the way in which a multidisciplinary approach to sustainability of solar energy should be embodied in regulations, policies, programs and activities in Iran. Sustainable solar energy development is a complex concept covering a multidisciplinary wide range of social, technical, economic and environmental issues; and without analyzing appropriately all these dimensions, sustainable solar energy development would not be complete. Therefore, sustainable solar energy development should include not only technological analysis and economic evaluation, but also legal, environmental and social considerations. Then it is necessary to look at the complex solar-energy system as a whole and see if the individual components accomplish the main objectives and obligations relating to the system.

\section{Pillars and Objectives of Sustainable Development of Solar Energy}

When human development aspirations and the capacity of the environment to support them are on a collision course, sustainable development, as an overarching principle come to the fore, according to which governments would seek a nationwide or worldwide policy-regulation framework to address the challenges of unsustainable development patterns and to regulate such patterns (Sara Parkin, 2004).

The term 'sustainable development' was popularized in 1987, in a report titled 'Our Common Future', known as the Brundtland report, published by the World Commission on Environment and Development (The Experts Group on Environmental Law of the World Commission on Environment and Development (Brundtland Commission), 1987). The most widely used definition of sustainable development was introduced by Our Common Future as "development that meets the needs of the present without compromising the ability of future generations to meet their own needs" (Report of the United Nations Conference on Environment and Development, 1997). Then the United Nations General Assembly accepted the report and gave the term political salience. However, the application of the principle was complicated and not successful altogether. As States and governmental and non-governmental organizations turned to designing and trying to implement relevant policies, they discovered that the definition referred to above, however apt, needed expanding if it was to provide a useful operational framework. Meeting the four following goals at the same time might be inevitable to achieve a practical sustainable development at the national level: (a) social progress which recognizes the needs of everyone, (b) effective protection of the environment, (c) diligent use of natural resources, and (d) maintenance of high and stable levels of economic growth and employment (Sara Parkin, 2004).

The seven principles of sustainable development proposed by the International Law Association (ILA) are as follows: (1) the duty to ensure sustainable use of natural resources; (2) the principle of equity and the eradication

\footnotetext{
${ }^{1}$ Our carbon footprint is the sum of all emissions of $\mathrm{CO} 2$ (carbon dioxide) which was induced by our activities in a given time frame (typically one year).
} 
of poverty; (3) the principle of common but differentiated responsibility; (4) the principle of the precautionary approach to natural resources, human health and ecosystems; (5) the principle of public participation and access to information and justice; (6) the principle of good governance; and (7) the principle of integration and interrelationship, in particular relating to human rights and social, economic and environmental objectives. ${ }^{2}$ The principles recognize differences in the contributions of States to global environmental problems, and differences in their respective economic and technical capacity to pursue sustainable development.

Further development happened in 1992, in Rio de Janeiro (The Report of the United Nations Conference on Environment and Development Rio de Janeiro, 1992), where 172 Governments adopted three major agreements to guide future approaches to development: (a) Agenda 21, an unprecedented global plan of action for sustainable development, (b) a global plan of action to promote sustainable development; and (c) the Rio Declaration on Environment and Development. In 1997, General Assembly in its 19th special session (United Nations General Assembly, 1997) reviewed and appraised the implementation of Agenda 21. ${ }^{3}$

Principle 2 of the Rio Declaration, ${ }^{4}$ as an integration between environmental protection and development, which is inherent in the concept of sustainable development could be traced to the provisions of many international treaties. The essence of sustainable development is 'meeting the human needs, while preserving the life support systems of the planet' (Robert et al., 2001). Indeed, 'its strength lies in reconciling real and perceived conflicts between the economy and the environment and between the present and the future' (US National Research Council, 1999; Yohe et al., 2007). In the Gabčikovo-Nagymaros case, the International Court of Justice (ICJ) recalled that '[t]his need to reconcile economic development with protection of the environment is aptly expressed in the concept of 'sustainable development' (The Case Concerning the Gabčíkovo-Nagymaros Project, 1997), which 'increasingly is at the core of international environmental law' (International Law Association, 2004).

Additional reference should be made to Principle 1(1) of the New Delhi Declaration on Sustainable Development (2002), as one example of international declarations and resolutions, which would contribute 'significantly to the process of custom generation' (McIntyre, 2006), especially in terms of the development and codification of international environmental rules and principles, pronounces that:

Indeed, it is a well-established principle that, in accordance with international law, all States have the sovereign right to manage their own natural resources pursuant to their own environmental and developmental policies (International Law Association (ILA), New Delhi Declaration of Principles of International Law Relating to Sustainable Development, 2002). ${ }^{5}$

As regards Agenda 21 referred to above, it should be noted that the importance of Agenda $21^{6}$ to the issue of sustainable development, lays in the fact that it addresses, among other issues, the most complicated crucial questions of the world, that is, combating poverty, protecting the atmosphere, combating deforestation, sustaining biological diversity, safeguarding ocean resources, managing hazardous wastes, and ways of obtaining the financial resources required to tackle those problems (UN Doc, 1997). In 1997, the UN General Assembly considered reasons why goals set in the 1992 Rio have not always been met and suggested corrective action, and highlighted special issues, such as, use of energy and transportation, finance and technology transfer, patterns of production and consumption, finally called on Governments, international organizations and major groups to renew their commitment to sustainable development.

\footnotetext{
${ }^{2}$ For further, see International Law Association (ILA), New Delhi Declaration of Principles of International Law Relating to Sustainable Development (ILA, 2002), at 9; ILA, New Delhi Declaration, Resolution 3/2002, (2002); ILA, Report of the $69^{\text {th }}$ Conference, (London, 2000), at 22 .

${ }^{3}$ The programme of action was adopted by the United Nations Conference on Environment and Development (UNCED) held in Rio de Janeiro in 1992. Agenda 21 consists of a preamble and 40 chapters divided into programme areas addressing topics in terms of basis for action, objectives, activities, and means of implementation. The issues referred to in the text are addressed in chapters of Agenda 21.

${ }^{4}$ Principle 2 of the Rio Declaration reads as follows: 'States have, in accordance with the Charter of the United Nations and the principles of international law, the sovereign right to exploit their own resources pursuant to their own environmental and developmental policies, and the responsibility to ensure that activities within their jurisdiction or control do not cause damage to the environment of other States or of areas beyond the limits of national jurisdiction'.

${ }^{5}$ For further, see Sands, P., 'Environmental Protection in the Twenty-first Century: Sustainable Development and International Law', in Vig, N.J., and Axelrod, R.S., The Global Environment: Institutions, Law, and Policy (Earthscan, London, 1999),116-137, p. 127; see also Sands, P., Principles of International Environmental Law ( $2^{\text {nd }}$ ed.), (Cambridge University Press, Cambridge, 2003), p. 235-6; Lefeber, R., Transboundary Environmental Interference and the Origin of State Liability (Kluwer Law International, The Hague, 1996), p. 23; McIntyre, O., Environmental Protection of International Watercourses under International law (Ashgate Publishing Ltd., Aldershot, 2007), pp. 201 and 164.

${ }^{6}$ See further, Report of the United Nations Conference on Environment and Development, Rio de Janeiro, 3- 14 June 1997, vol. I, Resolutions adopted by the Conference (United Nations publication, Sales No. E.93.I.8 and corrigenda), resolution 1, annex II.
} 
At the ninth session of the Commission on Sustainable Development (CSD-9) in 2001 (UN Commission on Sustainable Development, 2001), key energy issues were discussed. In 2002, at the World Summit on Sustainable Development (WSSD) held in Johannesburg, (UN, 2001), the international community agreed to facilitate access for the poor to reliable and affordable energy services in the context of broader national policies to foster sustainable development. The WSSD, moreover, called for changes in unsustainable patterns of energy production and use. It is hence important for States and policy makers to understand and consider the implications and positive and negative impacts of different energy programs, alternative policies in shaping progress within a country and on the feasibility of making this development sustainable over a period of time (I. A. Vera et al., 2005).

\section{Case Study: U.S. Investment Tax Credit and Energy Policy Act}

Despite the advantages of using solar energy, such as reducing greenhouse gases, it is important to note that solar power is 2.5 to 5 times as expensive as electricity from existing conventional power sources, such as coal and other sources. In order to encourage American people to use solar power, the Energy Policy Act of 2005 (U.S. House of Representatives, 2005) ${ }^{7}$ in the U.S. was adopted, thereby the federal tax credit or Investment Tax Credit (ICT) ${ }^{8}$ for residential energy property was established and initially applied to solar-electric systems, solar water heating systems and fuel cells.

In the U.S., the ITC is one of the most important federal policy mechanisms to support the deployment of solar energy. It applied to projects placed in service between January 1, 2006 and December 31, 2007. In 2006, the Tax Relief and Health Care Act extended these credits for one additional year through the end of 2008. An eight-year extension of the residential and commercial ITC was included in the 2008 Emergency Economic Stabilization Act. Also the monetary cap for residential solar electric installations was eliminated and utilities and companies paying the alternative minimum tax (AMT) were permitted to qualify for the credit. Then in 2015, a multi-year extension of the residential and commercial ITC was included by the 2015 Omnibus Appropriations Act. It also changed the previous "placed-in-service" standard for qualification for the credit to a "commence construction" standard for projects completed by the end of 2023.

A tax credit is a dollar-for-dollar reduction in the income taxes that the person claiming the credit would otherwise have to pay the federal government. As a credit, you take the amount directly off your tax payment, rather than as a deduction from your taxable income. Other than the cost of the system, there is no limit to the dollar amount of the credit. To claim the credit, you must file the Internal Revenue Service ("IRS") Form as part of your tax return. You calculate the credit on the form.

As mentioned above, the Act was reviewed and the ICT was extended several times. The 2008 Energy Improvement and Extension Act extended the tax credit to small wind-energy systems and geothermal heat pumps (The American Recovery and Reinvestment Act of 2009, 2009). ${ }^{9}$ Installing alternative energy equipment in your home can qualify you for a credit equal to $30 \%$ of your total cost. The credit is available through the end of 2019. After that, the percentage steps down each year and then stops at the end of $2021 .^{10}$ After 2015 , the law extends the 30\% Solar Investment Tax Credits for both residential and commercial projects through the end of 2019 , and then drops the credit to $26 \%$ in 2020 , and $22 \%$ in 2021 before dropping permanently to $10 \%$ for commercial projects and $0 \%$ for residential projects. Furthermore, commercial and utility projects which have commenced construction before December 2021 may still qualify for the 30,26 or 22 percent ITC if they or their projects are placed in service before the end of 2023 (Solar Energy Industries Association (SEIA), Impacts of Solar Investment Tax Credit Extension).

As a result of the multi-year extension of the Solar ITC, which will lead to sustained growth in the U.S. solar industry, it has been expected a solar price to continue to fall while installation rates and technological

\footnotetext{
${ }^{7}$ The Energy Policy Act (EPA) addresses energy production in the United States, including: (1) energy efficiency; (2) renewable energy; (3) oil and gas; (4) coal; (5) Tribal energy; (6) nuclear matters and security; (7) vehicles and motor fuels, including ethanol; (8) hydrogen; (9) electricity; (10) energy tax incentives; (11) hydropower and geothermal energy; and (12) climate change technology.

${ }^{8}$ For further, see US. Environmental Protection Agency (EPA), 'A Guide to Federal Tax Incentives for Brownfields Redevelopment', Brownfields Federal Programs Guide, EPA, U.S. 2014.

${ }^{9}$ Entered into force, January 1, 2008. Other key revisions included an eight-year extension of the credit to December 31, 2016; the ability to take the credit against the alternative minimum tax; and the removal of the $\$ 2,000$ credit limit for solar-electric systems beginning in 2009 . The credit was further enhanced in February 2009 by The American Recovery and Reinvestment Act of 2009, which removed the maximum credit amount for all eligible technologies (except fuel cells) placed in service after 2008.

${ }^{10}$ Qualifying equipment includes solar-powered units that generate electricity or heat water. The credit is only available for improvements you make to your residence. This can apply to a second residence as well.
} 
efficiencies will continue to climb. As outlined above, the ICT, which initially was established by the Energy Policy Act of 2005 in the U.S., is a dollar-for-dollar reduction in the income taxes and will drop permanently to $10 \%$ for commercial projects and $0 \%$ for residential projects. As a result of the extension, the roughly 210,000 Americans currently employed in solar which is expected to double to 420,000 by the end of 2020 ; it has been expected the roughly 27 gigawatts of solar energy cumulatively installed in the US at the end of 2015 which will deploy around 20 gigawatts of solar electric capacity annually to reach nearly 100 gigawatts by the end of 2020; all this while spurring roughly $\$ 140$ billion in economic activity (Ibid).

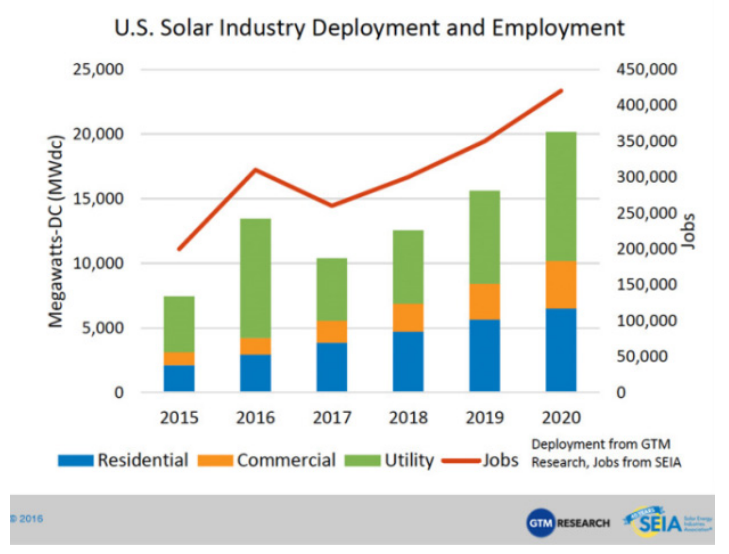

Source: Solar Energy Industries Association (SEIA), 2016

\section{Conclusion}

The transition from fossil fuel energy to renewable energy, as a means, inter alia, to reduce $\mathrm{CO} 2$ emissions, requires nationwide the adoption of the sustained regulation on renewable, especially solar energy, as the cleanest sources to produce energy, taking a multidisciplinary approach. Such perspective involves converging appropriately multiple disciplines and expertise to redefine problems relating to sustainable development of solar renewable energy outside normal boundaries and reach solutions based on a new understanding of complex questions. Sustainable development of solar energy should be based on four important and basic goals.

The achievement of the goals at the same time is the key feature of sustainability. Indeed, such objectives should be included and could be achieved through regulation, a policy or program, such as the establishment of stable and long-term tax incentives for the development of sustainable solar energy. Such tax incentives can drive economic growth while reducing prices and creating jobs in a country.

One of the main purposes of this paper is to outline the possibility of the realization of the goals through the establishment and advancement of a policy and regulation on sustainable solar energy development. For this purpose, as a case study, we have examined U.S. legislation, that is, the Energy Policy Act of 2005 in the U.S. which established and then continued to extend ICT. It is an example of a multidisciplinary approach towards sustainable solar energy development through regulation.

The example discussed in this paper shows how regulation and policy could contribute to sustained development of solar energy, taking a multidisciplinary approach. The achievement of four goals of a sustainable development can be seen in the regulation. Meeting the four goals at the same time is necessary to achieve a practical sustainable development at the national level: (a) diligent use of natural resources, and (b) maintenance of high and stable levels of economic growth and employment, (c) social progress which recognizes the needs of everyone, and (d) effective protection of the environment. Solar energy is considered as the potential cleanest source of energy and solar power reduces our use of fossil fuels and does not pollute, which can help reduce our individual carbon footprint.

In order to gain the goals, it is necessary to set forth nationwide the relevant rights and obligations of the State and private companies, to incentivize solar energy through even tax reduction and create a new culture on using such energy, as well as to provide the legal basis upon which to pursue the sustainable development goals for solar energy in Iran. Furthermore, it would seem very useful to take a multidisciplinary approach and at least establish a group of experts nationwide, first, to address sustainable solar energy development (SSED), second, to develop a comprehensive resource Foundation to consider and analyze a set of multidisciplinary case studies, 
third, to support and aid public and private sectors in understanding the inevitable SSED impacts on Iran and concepts inherent in sustainability and how solutions can practically be developed in any solar-energy project. There is a need to develop an integrated, holistic regulatory framework for solar energy, that is, integrate energy into the legal, social, economic and environmental programs, based on our abilities to address the most important energy-related issues.

\section{References}

Alamdari, P., Nematollahi, A., \& Alemrajabi, A. (2013, December). Solar energy potentials in Iran: A review. Renewable and Sustainable Energy, 21, 778-788. https://doi.org/10.1016/j.rser.2012.12.052

International Law Association (ILA). (2002). New Delhi Declaration of Principles of International Law Relating to Sustainable Development (ILA).

International Law Association, New Delhi Declaration, Resolution 3/2002. (2002).

International Law Association, Report of the 69th Conference, ILA, London. (2000).

International Law Association, Report of the Seventy-first Conference, (Berlin, 2004), Commentary to Article 3 of the 2004 Berlin Rules on Water Resources.

Kates, R. W., Clark, W. C., Corell, R., Hall, J. M., Jaeger, C. C., Lowe, I. ...Svedin, U. (2001). Environment and Development: Sustainability Science. Science, 292, 641-642. https://doi.org/10.1126/science.1059386

Khorasanizadeh, H., \& Mohammadi, K. (2013, July). Prediction of daily global solar radiation by day of the year in four cities located in the sunny regions of Iran. Energy Conversion and Management, 76, 385-392. https://doi.org/10.1016/j.enconman.2013.07.073

Lefeber, R. (1996). Transboundary Environmental Interference and the Origin of State Liability. Kluwer Law International, The Hague.

McIntyre, O. (2006). The Role of Customary Rules and Principles of International Environmental Law in the Protection of Shared International Freshwater Resources. Natural Resources Journal, 46(1), 157-210.

McIntyre, O. (2007). Environmental Protection of International Watercourses under International law. Ashgate Publishing Ltd., Aldershot.

Mohammadi, K., Mostafaeipour, A., \& Sabzpooshani, M. (2014, February). Assessment of solar and wind energy potentials for three free economic and industrial zones of Iran. Energy, 21, 1-12. https://doi.org/10.1016/j.energy.2014.02.024

Najafi, G., Ghobadian, B., Mamat, R., Yusaf, T., \& Azmi, W. H. (2015, April). Solar energy in Iran: Current state and outlook. Renewable and Sustainable Energy, 49, 931-942. https://doi.org/10.1016/j.rser.2015.04.056

Report of the United Nations Conference on Environment and Development, Rio de Janeiro, 3- 14 June 1997, vol. I, Resolutions adopted by the Conference (United Nations publication, Sales No. E.93.I.8 and corrigenda), resolution 1, annex II.

Sands, P. (1999). Environmental Protection in the Twenty-first Century: Sustainable Development and International Law. In Vig, N. J., \& Axelrod, R. S. (Eds.), The Global Environment: Institutions, Law, and Policy (pp. 116-137). Earthscan, London.

Sands, P. (2003). Principles of International Environmental Law (2nd ed.). Cambridge University Press, Cambridge. https://doi.org/10.1017/CBO9780511813511

Sara Parkin, O. B. E., Johnston, A., Buckland, H., Brookes, F., \& White, E. (2004). Learning and Skills for Sustainable Development Developing a Sustainability Literate Society. Higher Education Partnership for Sustainability, London, p. 5.

Solar Energy Industries Association (SEIA), 'Impacts of Solar Investment Tax Credit Extension. (2016). Retrieved from www.seia.org

The American Recovery and Reinvestment Act of 2009 (ARRA) (Pub.L. 111-5), (The Stimulus or The Recovery Act), 111th United States Congress, February 2009 and signed into law on February 17, 2009.

The Case Concerning the Gabčíkovo-Nagymaros Project, (Hungary v. Slovakia), Judgment, ICJ Reports, (1997), 7.

The Experts Group on Environmental Law of the World Commission on Environment and Development (Brundtland Commission), Environmental Protection and Sustainable Development: Legal Principles and 
Recommendations (Graham and Trotman/Martinus Nijhoff, London, 1987).

The Fifth Five Year Economic, Social \& Cultural Development Plan of the Islamic Republic of Iran, January 15, 2011.

The Report of the United Nations Conference on Environment and Development Rio de Janeiro, UNCED, June 1992.

U.S. House of Representatives, 109th Congress Report, 109-190 (Conference Report), Energy Policy Act, 2005.

UN Commission on Sustainable Development (CSD-9), UN, New York, 2001.

UN Doc., GA/9257 ENV/DEV/423 20 June 1997.

United Nations General Assembly, 19th special session to review and appraise the implementation of Agenda 21, New York, 23-27 June 1997.

US National Research Council, (ed.), Our Common Journey: A Transition toward Sustainability, (National Academy Press, Washington, 1999), pp. 21-58.

US. Environmental Protection Agency (EPA), 'A Guide to Federal Tax Incentives for Brownfields Redevelopment', Brownfields Federal Programs Guide, EPA, U.S. 2014.

Vera, I. A., Langlois, L. M., Rogner, H. H., Jalal, A. I., \& Toth, F. L. (2005). Indicators for sustainable energy development: An initiative by the International Atomic Energy Agency. Natural Resources Forum, 29, 274 283. https://doi.org/10.1111/j.1477-8947.2005.00140.x

\section{Copyrights}

Copyright for this article is retained by the author(s), with first publication rights granted to the journal.

This is an open-access article distributed under the terms and conditions of the Creative Commons Attribution license (http://creativecommons.org/licenses/by/4.0/). 